\title{
This Side of the Cornfield: Reform Activism at Graceland College, 1965-1973
}

\section{DAVID ANTHONY TYEEME CLARK}

"THE OTHER SIDE OF THE CORNFIELD," a series of articles by Graceland College student Greg Walden, appeared in the Graceland Tower during the spring semester in 1970. In his articles Walden hoped to refocus students' attention away from daily life at Graceland to national issues. Walden addressed alternatives to the draft, psychological damage due to military service, the size of the defense budget, and groups such as the Black Panthers and the Chicago Eight.

In recent years, historians have given increasing attention to the protest movements of the 1960s and 1970s. Yet with their focus on large cities and large universities, they have largely ignored countless Greg Waldens at unfamiliar-sounding places such as Graceland College. Reversing Greg Walden's trajectory, I hope to refocus attention away from large cities and universi-

I presented an earlier version of this paper at the John Whitmore Historical Society Annual Meeting in October 1989. As with all scholarly efforts, this one is the product of numerous collaborations. Above all, I want to express gratitude to my undergraduate mentor and friend, Bill Juhnke, and to the living, breathing "informants" for this study, in particular Alma Blair, Howard Booth, Steve Byrn, Tom Freeman, Brian Hice, Barbara Higdon, Jim Johnson, Marian Killpack, Bill Russell, and Greg Sutherland. I also want to thank David Katzman and Rusty Monhollan for their recent comments and insights, as well as express my gratitude to Cheryl Patterson, Richard Tubbs, and Marilyn Smith for listening to my thoughts about white reform activism and its limits. Finally, I would like to thank my former students at Community College of Aurora, Colorado, especially Tanya Batzel, Tom Nucci, Gene O'Neil, Tonna Pallas, Ronnie Peacock, and Jerry Valdez. Their words continue to teach me about the construction of knowledge and meaning.

THE ANNALS OF IOWA 59 (Winter 2000). CThe State Historical Society of Iowa, 2000. 
ties on "the other side of the cornfield" to smaller colleges and communities on "this side of the cornfield." If the "geography of activism" is as important as Terry Anderson suggests, and if the Vietnam War was "an American ordeal," as the late Charles DeBenedetti maintained, then it is important to include the experiences of small, rural colleges in the larger story of reform activism in the 1960s and 1970s.'

The story of reform activism at Graceland College calls into question the declension narrative that dominates scholarly interpretations of this period. In that narrative, the intensity of protests generally diminished over time because citizens largely did not support them, unrealistic goals proved unreachable, or the tediousness of movement activities outweighed the payoff from endless confrontation. ${ }^{2}$ Even for scholars who have questioned that narrative, urban experiences tend to characterize reform activism more generally. ${ }^{3}$ Reform activism at Graceland College

1. Terry H. Anderson, The Movement and the Sixties: Protest in America from Greensboro to Wounded Knee (New York, 1995); and Charles DeBenedetti and Charles Chatfield, An American Ordeal: The Antiwar Movement of the Vietnam Era (Syracuse, NY, 1990). Of course, the Graceland example does not apply to all rural, small, religiously affiliated colleges, nor is the story I tell the whole story. For another kind of local response to the war in Vietnam and antiwar protest, see Kenneth Heineman, "The Silent Majority Speaks: Antiwar Protest and Backlash, 1965-1972," Peace \& Change 17 (1992), 402-33. For an earlier effort to document local experiences, see Vietnam Hearings: Voices from the Grass Roots (Garden City, NY, 1966). More recent efforts to analyze local stories about the new left, political culture, and reform activism include Kenneth J. Heineman, Campus Wars: The Peace Movement at American State Universities in the Vietnam Era (New York, 1993); and Doug Rossinow, The Politics of Authenticity: Liberalism, Christianity, and the New Left in America (New York, 1998).

2. For this declension narrative, see especially Allen J. Matusow, The Unraveling of America: A History of Liberalism in the 1960s (New York, 1984); William L. O'Neill, Coming Apart: An Informal History of America in the 1960s (New York, 1971); David Burner, Making Peace with the 60s (Princeton, NJ, 1996); and Roger Rosenblatt, Coming Apart: A Memoir of the Harvard Wars of 1969 (Boston, 1997).

3. Efforts to undermine the declension narrative include David Farber, The Age of Great Dreams: America in the 1960s (New York, 1994); and Edward P. Morgan, The Sixties Experience: Hard Lessons about Modern America (Philadelphia, 1991). Two recent efforts to rethink postwar social change along a longer trajectory and against the declensionist narrative are James J. Farrell, The Spirit of the Sixties: Making Postwar Radicalism (New York, 1997); and Manning Marable, Race, Reform, and Rebellion: The Second Reconstruction in Black America, 1945-1990, 2d ed. (Jackson, MS, 1991). Accounts of women's liberation movements and radical feminism that avoid the declensionist model include Sara M. Evans, Per- 
between 1965 and 1973, rather than "unraveling" or "coming apart" over time, moved from the margins after 1967 into the mainstream well into the 1970s while reconstituting relationships among administrators, faculty, and students. Graceland changed during the eight years after 1965. Changes in the college's generational and gender arrangements were the movement's most tangible legacy-a legacy only indirectly inspired by the national antiwar protest movement and the New Left. In the wake of the movement, students became more involved in college governance, the college became more aware of its obligation to serve broader communities, and it incorporated demands for equal treatment of women into its institutional arrangements.

GRACELAND COLLEGE is located approximately three miles from the Missouri-Iowa border in Decatur County, Iowa. From its vantage point on a hill, the administration building overlooks Lamoni, a rural, farming community with a population of just under 1,000, as well as the surrounding countryside distinguished by cornfields and cattle. Members of the Reorganized Church of Jesus Christ of Latter Day Saints (RLDS) established Graceland College in 1895. By 1960, Lamoni commerce depended on college students, some of whom had more money to spend in local stores and restaurants than did many Lamoni natives and residents of nearby farms. ${ }^{4}$

Like many other colleges and universities across the country, the Graceland campus community grew dramatically during the 1960 s. Over the course of a decade, student enrollment increased

sonal Politics: The Roots of Women's Liberation in the Civil Rights Movement and the New Left (New York, 1980); and Alice Echols, Daring to Be Bad: Radical Feminism in America, 1967-1975 (Minneapolis, 1989). For an excellent review of recent scholarship through the lens of an academic generational conflict, see Rick Perlstein, "Who Owns the Sixties?: The Gap of a Scholarly Generation Gap," Lingua Franca: The Review of Academic Life 6 (1996), 30-37.

4. Sympathetic and thoughtful histories of Graceland College include Roy A. Cheville, Through the West Door: The Story of the First Half Century of Graceland College (Independence, MO, 1946); and Paul M. Edwards, The Hilltop Where: An Informal History of Graceland College (Lamoni, 1972). For a short, accessible history of the RLDS Church, see Paul M. Edwards, Our Legacy of Faith: A Brief History of the Reorganized Church of Jesus Christ of Latter Day Saints (Independence, MO, 1991). 
62 percent from 887 in $1963-64$ to 1,429 in 1971-72. Trustees funded the construction or renovation of dormitories, classrooms, a new library, and a gymnasium with an indoor track. Today, the gymnasium and the administration building (newly renovated in 1997), along with the local grain elevator, are prominent objects on the physical landscape as traffic approaches Lamoni on Interstate 35 from either direction. ${ }^{5}$

Increasing enrollment prompted the addition of several young faculty members. Earlier in their lives as students, some of these new faculty had worked to reinforce or modify in loco parentis rules and, after 1965, to support or oppose U.S. involvement in the war in Vietnam. As new professors, some challenged traditional views governing college life. Some even participated in protests alongside student activists. Increasingly after 1965, reform-minded students, faculty, and administrators together debated the proper role of students in shaping institutional values, participated in heated discussions about American foreign policy, and challenged the legitimacy of in loco parentis policies that governed campus life. ${ }^{6}$

As it was elsewhere, reform activism at Graceland College was consistently symbolic, crafted to educate, or sometimes shock, and designed to influence local politics. It was also deeply personal; reform activists at Graceland stressed what

5. Official enrollment figures are listed in the Graceland College Bulletin and Official Catalogs. For an outline of new buildings and structures during the 1960s, see Dan Graybill and Elaine Graybill, eds., "History," Graceland Student Handbook (Lamoni, 1970), 59, Archives of Graceland College (hereafter AGC), Frederick Madison Smith Library, Graceland College, Lamoni; and Edwards, The Hilltop Where, 130-31.

6. Roger D. Launius, "Coming of Age: The Reorganized Church of Jesus Christ of Latter Day Saints in the 1960s," Dialogue: A Journal of Mormon Thought 28 (1995), 31-57, advances the notion that "liberal emphases" showed indirectly through complaints about the curricular choices of these new Graceland professors. "Church officials," Launius writes, "often heard criticism of these new faculty for undermining the faith of students in the 1960s." lbid., 42-43. For an analysis of the erosion of "the hegemony of college life" and how it turned "college youth into raging demonstrators disaffected from American society," see Helen Lefkowitz Horowitz, Campus Life: Undergraduate Cultures from the End of the Eighteenth Century to the Present (New York, 1987), 220-44. Her conclusion, drawn from evidence from larger and more elite universities, is supported by my observations of reform activism and its effects at Graceland College after 1965. 
James Farrell has called "the inviolable dignity of persons," and they hoped to, again in Farrell's words, "convert moribund individuals to moral action." Between 1967 and 1972, individuals within a mostly white, patriarchal campus community steered a course toward unprecedented student participation in campus government, curricular issues, and other academic matters. Reform activists also focused on matters not necessarily related to local concerns, but their passion about these matters was consistently personal. The draft and the war in Vietnam aroused reform-minded attempts to force the campus community to deal not only with U.S. foreign policy, but also with what reformers believed were related injustices and brutalities at home. ${ }^{8}$

Reforming student government and protesting U.S. involvement in the war in Vietnam by attacking the draft at Graceland were largely the activities of men in hierarchical settings. Graceland women, responding to long-standing traditions and attitudes that marginalized their participation in campus politics as well as to the new angles of vision that had emerged by 1968 , attacked the discriminatory enforcement of the on-campus housing code. The end of this discriminatory enforcement in 1972 , as well as the dismantling of in loco parentis policies more generally, marks a transition in an ongoing institutional renewal.

Between 1965 and 1973, reform-minded students, faculty, and administrators, collectively, underscored the benefits of a heterogeneous individualism for institutional health and well-being, emphasized (but did not fully realize) a participatory democracy that flattened hierarchical decision-making, and accentuated a community ethos that connects the personal with the political

7. Farrell, The Spirit of the Sixties, especially 5-19. One of the most important developments of the 1960s was the discovery among white reform activists that the personal is political. See Evans, Personal Politics.

8. My work, like the historiography of student activism, antiwar actions, and the peace movement, reflects an emphasis on white reform activism. See Elizabeth Martínez, "Histories of 'the Sixties': A Certain Absence of Color," Social Justice 16 (1989), 175-85. Graceland apparently started recruiting AfricanAmerican students from Chicago sometime during the late sixties. Once at Graceland, these students shared a house located just off campus. They organized a black caucus in an effort to personalize campus politics. I found no trace of any interaction between black students at Graceland and white reform activists, a silence I interpret as illustrating the racialized nature of reform activism at Graceland. 
and the local with broader worlds. By 1973, reform-minded members of the Graceland College community had successfully institutionalized, some might argue absorbed or co-opted, the version of sixties reform activism developed at Graceland.

REFORM ACTIVISM on college campuses during the 1960s and 1970s has become nearly synonymous with antiwar protest. Yet at Graceland College antiwar activity was only one aspect of a much broader and, at the same time, much more localized and more durable reform agenda. The actions and experiences of Michael Williams, for instance, help make sense of a reform agenda that dominated campus discourse for nearly a decade.

While a student at Graceland, Williams was a well-known critic of the war in Vietnam. But for Williams, the war was only one of several issues on a much broader reform agenda that included greater student involvement in the decisions that affected them. ${ }^{9}$ Because military spending or defense industry research or investment was not a local issue at Graceland, the related symbols of war research and the Reserve Officers Training Corps (ROTC) that so effectively enabled antiwar activists at other campuses to implicate their administrations and faculty in the war machine were unavailable to Graceland activists. ${ }^{10}$ Instead they found local symbols of corruption or hypocrisy useful for rallying broader campus support.

In his junior year (1966-67), Williams's pronouncements through the campus newspaper and his campaign for president of the Cooperative Government Association illustrate how he

9. As a sophomore in 1965, Williams publicly opposed the war. See Graceland Tower, 5 and 19 November 1965.

10. See Heineman, Campus Wars; idem, "'Look Out Kid, You're Gonna Get Hit!': Kent State and the Vietnam Antiwar Movement," in Give Peace a Chance: Exploring the Vietnam Antiwar Movement, ed. Melvin Small and William D. Hoover (Syracuse, NY, 1992), 214, 216; Dick Cluster, "Rebellions Outside Ourselves: The Emergence of White Student Protest," in They Should Have Served That Cup of Coffee, ed. Dick Cluster (Boston, 1979), 114-15; Jonathan Goldstein, "Vietnam Research on Campus: The Summit/Spiceback Controversy at the University of Pennsylvania, 1965-1967," Peace \& Change 11 (1986), 27-43, reprinted in Sights on the Sixties, ed. Barbara L. Tischler (New Brunswick, NJ, 1992), 43-61; and Vietnam: The War at Home, prod. and dir. Glenn Silber and Barry Alexander Brown, 100 min., Maljack Productions, 1986, videocassette. 
and other reform-minded folks hoped to reconstruct campus life. Williams and his supporters had four targets around which they inspired support and rankled opposition: the dual role of the dean of students as both counselor and disciplinarian, Christian fraternity and fellowship, student apathy, and students' role in developing college policies. Williams, who may have been a member of Students for a Democratic Society, imagined himself as speaking at Graceland for Mario Savio and Bettina Aptheker, student leaders in the Free Speech Movement at the University of California at Berkeley, and David Smith and Linda Crandal, student activists at Iowa State University, 100 miles north on I-35." Clearly, Williams was significantly influenced by the objectives of a broader student left in the United States and in Iowa when he advocated greater student influence in campus government, decisions about student life and entertainment, curricular offerings, and faculty hiring.

But Williams, a student from Olathe, Kansas, whose father was an RLDS church official, may have been influenced by his understanding of commitments made on his local campus as well. In its statement of purpose published in the official catalog in 1966, Graceland's administration maintained that it strove to base "its corporate life upon those characteristics of Christian fraternity [such as] fellowship, mutual concern, love, the sense of obligation of each to minister to the needs of the other, respect for the dignity of each person, and concern for the larger world community." William Higdon, the incoming college president in 1965, echoing discourse in the upper echelons of the RLDS church, called on members of the campus community to get involved "in the world-wide problems that face our church and the nation."12

Williams's brand of reform activism reflected a similar view of Christian fellowship, one that stressed unconditional equality,

11. Professor Alma Blair, interview by author, Lamoni, 7 March 1989; Graceland Tower, 3 and 10 March 1967.

12. Graceland College Official Handbook, 1965-66, 9; Higdon, quoted in Graceland Tower, 11 February 1968. Some might argue that there was one notable exception to Higdon's support for personal liberties when, in 1968, he decided that an art professor's exhibit would not be displayed on campus. See Graceland Tower, 22 November 1968. 
broad personal liberties, and individual and group responsibilities. Speaking for what he called the "Coffee Shop Group" in February 1967, Williams described a fellowship that included a heterogeneous group of equal individuals who could offer a healthy atmosphere for "the smokers and the artists, the drinker and the writer, the promiscuous and the intellectually brilliant, the common and the extraordinary." ${ }^{13}$

Williams was not the first nor would he be the last member of the campus community to express such views and attract verbal opposition for doing so. Two years earlier, in 1965, John Gleazer, a freshman student from Washington, D.C., argued that his peers needed to abandon what he perceived as a "search for comfort and security" and instead to "identify with the world" by understanding why free speech in California, civil rights in the American South, and concern about the war in Vietnam interested students everywhere. Five years later, in 1970, the founding statement of Peace and Freedom Mobilization hinted at a Christian fellowship wherein individuals were responsible for group well-being. "All of us can hurt, can die, get angry, want to be loved," said the statement, "and all of us on this planet will make it together or we won't make it at all."14

Conservative-minded members of the campus community vigorously challenged reformers and their notions of Christian fellowship. Responding to John Gleazer in 1965, for example, Charles Patterson Curry, identifying himself as an alumnus, reminisced about a Graceland "different from the rest of the world [with] a unique atmosphere [where] things people elsewhere holler so loudly about aren't very important." He conceded that free speech, civil rights, and war protest were meaningful issues, but he also charged that such things "are marked by hotheadedness, radicalism, riots and ill feelings." 15

Driven by what could have been youthful rebellion and by a desire to liberate those he called Graceland's "whores" (including, presumably, himself), Michael Williams faced the prospect

13. Graceland Tower, 3 February 1967.

14. Graceland Tower, 8 October 1965; Peace and Freedom Mobilization, "Statement and Purpose," typescript, 1970, Private Papers of Howard Booth, Graceland College, Lamoni.

15. Graceland Tower, 5 November 1965. 
of being misinterpreted and misunderstood by people who did not look beyond what they viewed as inflammatory rhetoric. Some in the campus community, for example, labeled Williams an immature troublemaker and his vision anarchist. Responding to Williams's call for a cosmopolitan community, Carol Rosbury Rodwell, a former Graceland student, wrote, "Let's keep Graceland for those who are seriously striving for healthy, nonneurotic adulthood within the framework of an organized stable society."16

Early in the spring 1967 semester, Williams outlined his democratic vision and corresponding reform project in the college newspaper. In March and April he campaigned for president of the Cooperative Government Association (CGA). Professor Bill Russell (political science), an insider in Williams's crusade, suggested privately in a letter during the campaign that Williams "entered the race for CGA president ... only to get across some ideas. [He] had no thought of winning at all." Others saw Williams's bid as a "grab for power." Dean of Students Albert Fuller, for example, argued that Williams had not "consistently demonstrated a service attitude toward the campus." Instead, his campaign, according to Fuller, was aimed at "tearing down existing institutions and patterns." Fuller's remarks were a direct response to Williams's earlier comments in the campus paper that traditional religious, political, and economic structures were unresponsive to the needs of his generation. "The only way anything can be accomplished," he told a Graceland Tower reporter, is to create "sufficient friction" to force institutions "to fulfill the function for which they were created." ${ }^{17}$

"Dragging Graceland into the Twentieth Century," Williams's campaign slogan, signified reform-minded sentiment in 1967. The slogan suggests a distance (we are way behind and we

16. Graceland Tower, 3 March 1967. Williams used the term whores to expose what he considered ridiculous labels being applied by mainstream students and to refer to "virgins who have very low opinions of themselves because others think similarly of them, due to their slipping out of doors after hours, smoking, drinking, and indulging in other unapproved, i.e., deviant behavior." Graceland Tower, 3. February 1967.

17. Bill [Russell] to Dick and Reta, 21 April 1967, Private Papers of William D. Russell, Graceland College, Lamoni; Graceland Tower, 14 April and 3 March 1967. 
need to catch up) and a level of difficulty (it is not going to be easy). In his campaign platform, Williams outlined his plan to expand the CGA and thereby ensure "responsiveness to student welfare." He proposed "better communication through better representation," student authority in influencing the hiring and evaluation of faculty, and "a general opening of CGA channels to students." Not totally antiestablishment, Williams blamed students for failing to communicate with the administration, particularly the college president, who, according to Williams, was willing "to meet the students half-way."

Nonetheless, when Williams attacked Dean Fuller's "irreconcilable role of both counselor and disciplinarian" by labeling the dean's roles a "double-edged ambiguity," Fuller accused Williams of "resenting authority and authority figures" and of "attempting to do away with all existing regulations and authority." As for Williams's charge that his dual roles were "irreconcilable," Fuller assured students of the confidentiality of most information "about a past misdemeanor" shared in counseling. He did note, however, that there could be two exceptions: "(1). Where the student makes no subsequent efforts to correct the irregular or illegal behavior, despite counseling efforts; or (2). Where the information about the student's misdemeanor becomes public knowledge, bringing the standards of the college into public ridicule, and perhaps eroding or destroying these standards." ${ }^{19}$

Fuller did not specify what standards he intended to enforce, although his response to Williams provides some idea. Williams publicly supported and aligned himself with what he called the "Coffee Shop Group" and with a group he collectively characterized as "whores"-people who allegedly smoked cigarettes, consumed alcohol, and condoned premarital sex. He purposefully used confrontational rhetoric in his newspaper duel with Fuller. To people like Fuller, Williams must have appeared to support "irregular or illegal behavior."

18. Graceland Tower, 14 April 1967. Williams's support for President Higdon was well known and, I believe, sincere. See, for example, Graceland Tower, 10 February 1967.

19. Graceland Tower, 14 April 1967. 
In spite of energetic and organized efforts to discredit him, Williams defeated Larry Beal, a conservative Republican, who was the more acceptable candidate to Dean Fuller and others who shared his views. Following his victory, Williams and some of his friends celebrated the achievement at his off-campus apartment. Days later, an unnamed friend allegedly provided Fuller with information about "suspicious" activities at the victory celebration. ${ }^{20}$

After charges were leveled, William Higdon, the college president, acting in "the interest of fairness" and to minimize "polarization," appointed a four-member investigative committee to review the allegations prior to taking any action through the Council on Student Welfare (CSW) chaired by Fuller. The committee's members-Professor Paul Edwards (history), Professor Tom Freeman (psychology), Dean Fuller, and student Cameron Stuart-represented a range of sympathies from what might be characterized as oppositional to supportive. In May 1967 this investigative committee assured President Higdon that the charges against Williams were "reasonably founded." ${ }^{21}$

During the subsequent deliberations of the Council on Student Welfare (CSW), the administrative unit that heard the allegations against Williams, Fuller claimed that Williams was an active member of Students for a Democratic Society (SDS), perhaps hoping to take advantage of negative media treatment in the Des Moines Register and on the nightly television news. Alma Blair, a young history professor and CSW member in 1967, re-

20. For a sympathetic summary of Williams's campaign, see Russell to Dick and Reta, 21 April 1967, Russell Papers. Official election results are in L. D. Hansin, "Cooperative Government Association Election Results," typescript, April 1967, AGC. The significance of the 1967 election to members of the campus community can be interpreted from its turnout. In 1967, students, administrators, faculty, and staff could vote for the student CGA officers: 82 percent of the total CGA and 91 percent of the student body voted.

21. William T. Higdon to the author, 20 March 1989; William T. Higdon to the Graceland College Community, 17 May 1967, AGC. Edwards had worn a Williams campaign sticker and likely had voted for Williams in the recent election. Freeman, who linked antiestablishment campus politics with drug use, remembers Williams as being an instigator of unrest, disruption, and ill feelings in 1967. (Tom Freeman, interview by author, Lamoni, 8 March 1989.) Fuller's antipathy toward Williams was public and well known. Stuart's sympathies proved difficult to determine. 
calls that it was important for him at the time to help stop potential SDS influence and drug use at Graceland. Activism and SDS seem to have been metaphors for drug use and dishonesty for people such as Blair and Professor Tom Freeman, another CSW member who heard Williams's case. In May 1967 the CSW found Williams guilty on charges of drinking and entertaining unchaperoned women at his off-campus apartment, both infractions of student conduct. President Higdon, who "liked Mike," remembers finding no reason to veto the decision to suspend him for one year. ${ }^{22}$

Response to Williams's suspension was both immediate and long-term. First, early in June, more than 200 students and faculty signed a petition calling for a reevaluation of student disciplinary policies, a direct attack on Dean Fuller. ${ }^{23}$ Fuller defended his position until 1968, when he resigned. In September 1967, there was a broad-based effort that succeeded in amending the CGA constitution to prevent faculty and staff from voting in CGA elections. This was important for those who wished to reform campus government because, according to Bill Russell, during the CGA election in April of that same year, supervisors apparently told their staff to "get over there and vote because there is a young radical we've got to keep out of office. ${ }^{\prime 24}$

22. Des Moines Register, 18 May 1967; Blair interview; Freeman interview; Russell to Dick and Reta, 18 May 1967, Russell Papers; William T. Higdon to author, 20 March 1989; William T. Higdon to the Graceland College Community, 17 May 1967, AGC. Somewhere there is a reel-to-reel tape recording of Williams's hearing before the CSW. I was unable to locate it. Some considered the events that followed the CGA election partially, if not totally, the fault of Fuller. "Al Fuller had been laying for him and finally got him," wrote Bill Russell to Dick and Reta, 18 May 1967. According to Russell, some (unnamed) faculty members suggested that Williams's victory "would hurt the 'image' of the college" and that Williams "wasn't representative of the values upon which the college [was] based." Williams's CGA victory did, in a sense, bring "the standards of the college into public ridicule." The 1967 CGA election was broadcast locally on the radio news and made the front page of the Des Moines Register, 21 April 1967, where a staff writer branded Williams as a "supporter of the 'New Left' campus programs."

23. Portions of the petition's text are contained in Bill [Russell] to Bill [Higdon], 7 June 1967, Russell Papers. I was unable to find a copy of the petition.

24. Graceland Tower, 13 October 1968, and 22 September 1967; Russell to Dick and Reta, 21 April 1967, Russell Papers. 
The following fall students sought to reform the CGA further. A petition drive aimed to remove the threat of double jeopardy whereby a student could suffer penalties at the hands of both college authorities and off-campus civil authorities. That petition drive did not succeed. Then, in 1969, members of the Graceland community participated in a series of events that promoters called a constitutional convention. Those events laid the foundation for major changes in college government in the 1970s.

In 1970, Lloyd Young, dean of the college, and Brian Hice, CGA president, pushed for a campus-wide legislative senate modeled after similar institutions at Lehigh University in Pennsylvania and Union Theological Seminary in New York. When adopted, the new legislative senate at Graceland guaranteed student representatives a substantial role in determining institutional purposes and goals, campus life policies, and academic issues. During the 1970-71 school year, a newly created student academic council provided student involvement in decisions concerning course content, grading systems, degree requirements, and other academic matters. Despite the objections of some faculty who were concerned about transient students "changing something that is good for [them]," an overwhelming majority of the student body and the faculty voted in May 1972 to approve a new Graceland Student Government (GSG). Explaining the 527-27 margin of victory in February 1972, Hice suggested that students "are saying they have outgrown the CGA which they probably did five years ago [when they elected Michael Williams]."26

In April 1967, as Michael Williams prepared to leave Lamoni forever, he and his supporters had only begun to move people along the margins of the Graceland community into the mainstream. For the next five years, an energized and reorganized Graceland citizenry transformed the rights and responsi-

25. Graceland Tower, 25 October 1968 and 21 February and 2 May 1969.

26. Graceland Tower, 25 February 1972; Edwards, The Hilltop Where, 125-39. See also Brian Clark Hice, interview by author, Marshall, MI, 19 June 1989. The margin of victory also suggests that there was little opposition to changes in campus governance among students. Opposition came primarily from faculty and administrators who were concerned about students having too much power to shape the decisions that affected them. 
bilities of community membership and remade the institutional arrangements that governed people's lives in ways that extended well beyond the reforms articulated by Williams and his supporters during three exciting months in 1967. They would do so while a foreign war darkened the horizons and cast long shadows over lives on this side of the cornfield.

ORGANIZED ANTIWAR PROTEST at Graceland evolved from the Young Democrats' "evaluation" of Vietnam in November 1965 to symbolic protest in January 1973 of the renewed bombings of Hanoi and Haipong on December 18, 1972. At the height of locally organized antiwar actions-between October 1969 and May 1970-members of the campus community marched, lobbied, canvassed neighborhoods, wrote letters and telegrams, conducted symposiums, and campaigned on an assortment of issues somehow related to the war in Vietnam. Greg Walden, a second-year Graceland student, even testified before an ad hoc congressional committee in 1970. At every step, antiwar protest was fashioned to educate the campus and surrounding communities. National organizations and national protest strategies certainly influenced antiwar strategies at Graceland, but did not dictate them. Yet antiwar activists had few local targets for their protests. At Graceland, the war and those incriminated in waging it remained mostly an abstraction from the other side of the cornfields.

Nonetheless, debates over the war periodically energized the Graceland campus. In November 1965, the Young Democrats called for an end to a foreign policy that ignored human suffering. They also argued for a diplomatic strategy that would recognize the People's Republic of China and provide U.S. aid to all of Southeast Asia. On Sunday, March 27, 1966, the Young Democrats sponsored a teach-in titled, "Involvement in Vietnam: Perspectives." They advertised the event as "an educational instrument, presenting differing ideas on the Vietnamese problem." At the teach-in, four speakers, including a Democratic and a Republican candidate in the primary campaign for the U.S. Senate seat from Iowa, E. B. Smith and Herbert Hoover, addressed more than 200 Graceland students and faculty. The views expressed ranged from Hoover's firmly anticommunist 
pronouncements to the proposal from John Schuder of the University of Missouri that the probable communist domination that would result from American withdrawal would be a lesser evil than the present bombing and killing. ${ }^{27}$ The 1966 teach-in was significant because early in the war it legitimized dissent within intellectual forums.

Some members of the Graceland community were not prepared to legitimize dissent, however, especially as the draft became the focus of antiwar activities in 1966, 1968, and again in the spring of $1970{ }^{28}$ Not all Graceland students opposed the draft. In 1966 Dave Allen ridiculed the student left and its views on the draft, referring to war protesters as "peacemongers." Similarly, in 1968, responding to recent changes in draft law, Ernest Garner, Derald Hafner, and Pat Rounds attacked antidraft protesters. "Before students consider dissent," said Rounds, "they better learn to speak Chinese or Russian." Garner and Hafner suggested that everyone should accept the draft. "To try to avoid it," said Garner, "is immature; it's unpatriotic." Apparently agreeing with Garner, Hafner proposed, "If everyone who fights the draft would fight in other ways, we could help the situation. ${ }^{\prime 29}$

27. Graceland Tower, 12 November 1965 and 25 March and 2 April 1966. For the broader teach-in movement, which began at the University of Michigan in Ann Arbor after Lyndon Johnson decided to begin bombing North Vietnam in February 1965, see Louis Menashe and Ronald Rodosh, eds., Teach-ins: U.S.A.: Reports, Opinions, Documents (New York, 1967); William Haber, "Authority Without Freedom: The Birth of the Teach-In," Michigan Quarterly Review 7 (1968), 262-67; Jack Rothman, "The Radical Liberal Strategy in Action: Arnold Kaufman and the First Teach-In," Social Theory and Practice 2 (1972), 33-45; and DeBenedetti and Chatfield, An American Ordeal, 107-9.

28. In The Debate Over Vietnam, 2d ed. (Baltimore, 1995), David W. Levy argues that a two-part foreign policy consensus that had developed over the three decades after 1935 disintegrated after 1965 as Americans came to disagree over the legality and morality of the war in Vietnam. Opponents of the war branded those who disagreed with them militarists, baby-killers, tyrants, sadists, and fascists. The war's advocates did not hesitate to call antiwar activists cowards, communists, draft dodgers, traitors, appeasers, or collaborators. Both sides attempted to silence one another.

29. Graceland Tower, 6 May 1966 and 23 February 1968. Hafner and Garner's responses were included in a 1968 article, "What Will I Do When Drafted?" in which the weekly student newspaper reprinted numerous candid responses to the title question. 
Other students opposed antidraft activism even as they resented the draft. Alan Ourth, for example, didn't like "the idea of the draft" or "the new [draft] bill one bit," but was noncommittal about what he would do if drafted. Others, though they may have disagreed with U.S. foreign policy, admitted that they would not follow their conscience if drafted. Michael D. Wintermeyer, for example, didn't know what he would do; he didn't want to be drafted, but if he was, he admitted he would go. Jim Essex seemed similarly uncertain. "I'm not very much in favor of our presence in Vietnam," he commented, "but if I were drafted I would obey the Law of the Land. ${ }^{\prime 30}$

Typical antidraft protest at Graceland took the form of personal statements of conscience. In May 1967 Denny Derenzy and Dean Wight criticized the war in Vietnam by attempting to connect actions in Vietnam with a legacy of immorality that stretched back at least to the Second World War and by suggesting that the draft was immoral as a result. Michael Williams agreed, stressing the nature of the choice being forced upon many Americans by the war in Vietnam. "Our problem [in Vietnam]," he wrote, "is essentially a moral one. Is the harm we do (distorting values, killing innocent people, supporting a dictatorship ...) outweighed by the good we do? ${ }^{\prime 31}$

Three years after Derenzy and Wight took shots at the draft through the campus newspaper, Greg Walden notified his local draft board that he had sent his card to the Resistance, a group of "draft refusers" that sent draft cards to the Senate Armed Services Committee as part of a broader lobbying effort against the draft in 1970. Walden also rejected his II-S student classification, informing the local board that he would "no longer comply with any directives from the Selective Service System." Walden blamed national policymakers for "[subverting] the truth in a ruthless organized fashion." He could not, he wrote, participate in "the organized death machine which dominates this nation." By reprinting Walden's letter in the campus newspaper, editor Candy Morgan made the personal political, revealing personal statements of conscience to members of the

30. Graceland Tower, 23 February 1968.

31. Graceland Tower, 19 May 1967 and 19 November 1965. 
Graceland community and making the notion that the draft was part of the larger, increasingly corrupt "system" a part of discourses about the war and about student life at Graceland. ${ }^{32}$

Most, but not all, antidraft activity was intended primarily to educate the Graceland community about the draft and the war in Vietnam. In 1969 a group of antiwar students and professors known as the Peace Study Committee sponsored a "convocation on selective service and conscientious objection." This educational event featured James Closson, the college registrar and a member of the Decatur County draft board, and Wallace Kneyse, who powerfully pointed out the hypocrisy of the draft. Between March 15 and March 22, 1970, antidraft protest at Graceland was part of the larger Anti-Draft Days, organized in Iowa by the American Friends Service Committee. Activists passed out a schedule of speakers and films and distributed information from groups opposed to the war for various reasons. They also offered passersby an open letter to President Nixon printed by the Women's International League for Peace and Freedom, an issues-oriented peace group established long before the war in Vietnam; a statement of "Individuals Against the Crime of Silence," first circulated in 1967 by a group of California businessmen; and information from Business Executives Move for Vietnam Peace, a group that "opposed . . . the war in Vietnam not because it was wrong . . . but because it wasn't working., ${ }^{\prime \prime 3}$ The breadth of antiwar forces was manifest not only

32. Walden's letter to Michigan Local Board No. 85 was reprinted in Graceland Tower, 20 March 1970. For the dangers associated with Walden's act, see Morgan David Arant Jr., "Government Use of the Draft to Silence Dissent to War: A Case of Punitive Reclassification," Peace $\mathcal{E}$ Change 17 (1992), 147-71. For insiders' accounts of draft resistance, see Michael Ferber and Staughton Lynd, The Resistance (Boston, 1971); David Harris, Dreams Die Hard: Three Men's Journey through the Sixties (San Francisco, 1982); and Alice Lynd, comp., "We Won't Go: Accounts of War Objectors," Vietnam Generation 3 (1991), 80-96. An important macroanalysis of the Vietnam-era draft and its effects on the 27 million draft-age men is Lawrence M. Baskir and William A. Strauss, Chance and Circumstance: The Draft, the War, and the Vietnam Generation (New York, 1978).

33. Ken Lasater, Beth Higdon, Pat Savage, Robert Johnson, Greg Walden, and Greg Sutherland, Draft Action Days package of materials, March 1970, Booth Papers; Nancy Zaroulis and Gerald Sullivan, Who Spoke Up? American Protest against the War in Vietnam, 1963-1975 (Garden City, NY, 1984), 153. On the Women's International League for Peace and Freedom, see Charles DeBenedetti, The Peace Reform in American History (Bloomington, IN, 1980), 165-66, 
by the increasing number of participants in reform activities after 1969, but also in the diversity of the nationally organized contingents represented on campus and their ability to provide eclectic information to college students even in rural Iowa. Antiwar activists at Graceland pursued a strategy of infiltrating dominant discourses about the war with numerous and assorted available means that appealed to a widely shared notion that Graceland values could and should be applied to politics as well as to personal behavior.

To seize the opportunity to expand discourse about the war, there was a nationwide call in the fall of 1969 for a moratorium on college campuses on October 15 to promote discussions of U.S. involvement in the war in Vietnam. At Graceland, discussion of the October moratorium began in September among members of the CGA Executive Cabinet. Newell Yates, Albert Fuller's successor as dean of students, told members of the Executive Cabinet that their "Day of Protest" should be "constructive," reflecting, perhaps, a widely held image of antiwar activity between April 1965 and $1969 .^{34}$ In October, CGA senators discussed suggestions for various activities. Allen Rogers, designated as an "unofficial spokesman" by a "group of interested students on campus," proposed that antiwar literature be handed out to drivers on Highway 69. Others suggested scheduling guest speakers, sending letters to members of Congress, holding fasts, having discussions, and staging debates. Although the Executive Cabinet planned activities as a "protest,"

171, 173, 192; and Harriet Hyman Alonso, Peace as a Women's Issue: A History of the U.S. Movement for World Peace and Women's Rights (Syracuse, NY, 1993), 209-14, 219-20, 225-26.

34. Minutes, Cooperative Government Association, Executive Cabinet, 23 and 30 September 1969, AGC; Minutes, Cooperative Government Association, Senate, 1969, AGC; CGA Executive Cabinet, "The Vietnam Moratorium," typescript, 1969, Booth Papers. On the moratorium generally, see Fred Halstead, Out Now!: A Participant's Account of the Movement in the United States Against the Vietnam War (New York, 1991), 475-90; Vietnam Moratorium Committee, Vietnam: Why Americans Are Protesting (New York, 1969); and Paul Hoffman, Moratorium: An American Protest (New York, 1970). For accounts of the media's role in constructing an image of antiwar activities as not "constructive," see Todd Gitlin, The Whole World Is Watching: Mass Media in the Making and Unmaking of the New Left (Berkeley, CA, 1981); and Melvin Small, Covering Dissent: The Media and the Anti-Vietnam War Movement (New Brunswick, NJ, 1994). 
events discussed and later planned by the student senate were structured as an "educational experience" for both those who supported the war and those who were against it. In an early October faculty meeting, 39 members of the faculty, a majority (including Barbara Higdon, professor of English and wife of President William Higdon), asked the college administration to suspend classes in observance of a "discussion" on the war. President Higdon did so, publicly encouraging the Graceland community to take part in "activities designed to promote an understanding of, and an early end to, the war. ${ }^{\prime 35}$

Reform-minded faculty were consistently part of antiwar activities at Graceland, particularly Bill Russell, Barbara Higdon, and, after 1969, Howard Booth. ${ }^{36}$ In 1966, for instance, the Graceland chapter of the American Association of University Professors suggested that the administration refrain from providing information to the Selective Service System unless requested to do so by a student. ${ }^{37}$ Russell took a public stand against the war in Vietnam. Late in 1967 and again early in 1968, he openly criticized the Selective Service System and the draft. ${ }^{38}$ Barbara Higdon's support for what she referred to as college students "in most open rebellion," "a small but highly influential and articulate group [of students] ... who give form and basis to our religious culture," was well known. "In their search for their own identity," she wrote to an RLDS audience in 1965, "Latter

35. CGA Executive Cabinet, "The Vietnam Moratorium," Booth Papers; Graceland Tower, 2 and 9 October 1969; Minutes, Graceland College Faculty, 6 October 1969, AGC. Shortly after President Higdon's announcement, a Graceland Tower reporter polled 60 students and found that 25 planned to attend organized activities of the October moratorium; another 35 either were not going to participate or didn't even know what it was. This suggests that as much as 40 percent of the Graceland student body, having been excused by the college president from attending classes, intended to participate in or attend moratorium activities, though only about 10 percent of the Graceland community signed a petition opposing the war. Graceland Tower, 16 October 1969.

36. Launius, "Coming of Age?" 42-43, correctly points out that Graceland hired new faculty after 1960 who "were somewhat liberal in [their] beliefs," yet he fails to differentiate between liberal professors such as Howard Booth who actively opposed the war in Vietnam and those such as Robert Speaks who vocally supported the Johnson administration's foreign policy.

37. Graceland Tower, 20 May 1966.

38. Graceland Tower, 17 November 1967 and 23 February 1968. 
Day Saint college students ... will expect the church leadership to speak out loudly and clearly on moral issues that confront our society. They will urge radical institutional rebellion against prevailing social injustices and immorality in the conduct of our national affairs. ${ }^{139}$ In 1969 a number of faculty signed a petition declaring the war to be immoral and illegal. Following the escalation of the air war over North Vietnam in 1972 and the threat of Chinese intervention, Iowa's Democratic Senator Harold Hughes echoed the feelings of many Americans when he described the war in Vietnam as a "pointless, bloody intervention." In response to and in support of Hughes's opposition to the war, 13 Graceland College faculty, including Booth and Russell, asked, "Can we continue to let responsible people stand alone?"

During halftime of the homecoming football game in the fall of 1969, Howard Booth, Bill Howard (a Graceland alumnus and faculty member who had earlier favored changes to the organization of the student government), and six students marched in front of the home crowd. Mocking a military funeral procession and intending to shock the consciousness of onlookers, the marchers, accompanied by scattered boos and some applause, carried a black coffin-shaped box draped with an American flag while two students followed behind them beating drums. Years later Booth remembered the anxiety he felt as the group walked in front of a crowd at Graceland that included church president W. Wallace Smith and college administrators. "I was a new religion teacher," Booth recalled. "I was already labeled a liberal and a radical."

39. Saints' Herald, 15 October 1965. For a reaction to Higdon's characterization of college students, see Saints' Herald, 15 November 1965.

40. Des Moines Register, 18 April 1972; "Can We Continue to Let Responsible People Stand Alone?" [leaflet], n.d. [April 1972?], Russell Papers. The war in Vietnam was a central issue in lowa politics, particularly during and in the aftermath of the 1968 gubernatorial race. See Thomas Smith, "The Vietnam Era in Iowa Politics," Palimpsest 63 (1982), 138-41.

41. Professor Howard Booth, interview by author, Lamoni, 17 November 1988; William T. Higdon to author; Freeman interview. See also the photograph of the homecoming protest on the cover. Booth had been the RLDS campus minister at the University of Iowa in 1967 when Dow Chemical protests radicalized the university community in Iowa City. From 1969 through 1973, he both participated in antiwar protests at Graceland and provided moral leadership for dozens of students who felt alienated by policies of the broader RLDS Church. 
While some RLDS church leaders such as Booth supported students who had moral or other objections to the war in Vietnam, other church officials' public positions on the war and on conscientious objection contributed to the moral crises of young men such as Greg Walden. RLDS church president W. Wallace Smith, for instance, was "unalterably opposed" to communism. He told a crowd of nearly 2,000 church members in 1968 that they must "be involved" in Vietnam to combat the spread of communism. ${ }^{42}$ Resolution 1061 of the 1968 RLDS World Conference, presented by the Committee on Peace, War, and Use of Force and establishing official church doctrine, similarly offered little guidance for troubled church members. While acknowledging that "we oppose war," and that "conscientious objection by the individual does not reflect on his good standing in the church," the resolution also emphasized that "peace of conscience cannot be satisfied by mere nonparticipation in war. ${ }^{\prime \prime 3}$

Finding little support or direction for their position in such sentiment, and troubled by the nation's purpose in the war, reform activists such as Walden were often obliged to rely on their own spiritual or other outside resources to make sense of conflicting messages. When Greg Sutherland wrote to Carl Mesle, who chaired the RLDS's Ministry to Armed Forces Personnel, he received the same information the federal government had sent him. That information was not communicated in a manner sympathetic to the needs of those who, like Sutherland and Walden, had moral objections to the nation's military action in Vietnam. Feeling alienated and deserted by RLDS church leaders on this issue, Sutherland and other students obtained information and guidance from pacifist organizations such as the American Friends Service Committee, the Central Committee for Conscientious Objection, and liberal antiwar groups such as Clergy and Laymen Concerned About Vietnam. Perhaps more importantly, they received support through Christian fellowship and organized antiwar activity, from faculty members such

42. Quoted in "The Church and Vietnam," Armed Forces Newsletter 8 (February 1968), 2.

43. Committee Report on Peace, War, and Use of Force, World Conference 1968 (Independence, MO, 1968), 158-59. 
as Booth, Higdon, and Russell and, indirectly, from a largely sympathetic college administration. ${ }^{44}$

Such fellowship and support promoted efforts to institutionalize antiwar activism in the wake of the October moratorium. After October 15, Greg Walden, Mike Patterson, and Ralph Shaw organized what they called the Peace Study Committee (PSC), a group, according to the founding document, responsible for keeping informed about military conscription, conscientious objection, and other issues related to the war in Vietnam. Walden, Patterson, Shaw, and others hoped to understand how the war in Vietnam influenced their lives at Graceland, a difficult proposition in light of the impossibility of making direct connections between Graceland and the war through military research or ROTC training. ${ }^{45}$ The PSC, with advice and counsel from Sam Brown, co-coordinator of the Vietnam Moratorium Committee, encouraged members of the campus community to get involved in educational and symbolic protest activities. PSC members successfully recruited professors to talk about the war in their classes, and the group sponsored weekly films between October 29 and December 10. It also took news of the war off campus into town. On Thursday, November 13, the PSC and individual (at-large) members of SDS sponsored a symposium, a "fast for peace," and a march through the community, where they leafleted neighborhoods. During a mock memorial service outside the campus Commons that evening, PSC members read a list of the 44 RLDS members who had been killed in Vietnam since 1965 , then commemorated the loss of life in Vietnam by placing 44 crosses with those same names and the question, "Who's next?" on the Commons lawn. The next day, the group continued its fast for peace and its vigil outside the Commons. In December the PSC promoted Moratorium Days for Christmas on December 12-13 and 24, encouraged the campus community to support the boycott for peace sponsored by Christmas Buying

44. Sutherland interview. For the antiwar actions of the American Friends Service Committee, Central Committee for Conscientious Objection, and Clergy and Laymen Concerned About Vietnam, see DeBenedetti and Chatfield, An American Ordeal; and Zaroulis and Sullivan, Who Spoke Up?

45. Greg Walden and Ralph Shaw, Peace Study Committee Letter, typescript, [n.d.], photocopy, Booth Papers. 
Boycott for Peace in Pasadena, California, and suggested that members of the campus community contribute money to the Student Mobilization Committee, Clergy and Laymen Concerned About Vietnam, American Friends Service Committee, and the Vietnam Moratorium Committee. They called on people to "take the Moratorium home, and let those about you know your position." ${ }^{\prime 46}$

Reflecting the continuing and expanding influence of pacifists in antiwar discourse at Graceland, members of the PSC returned from Christmas break to found Peace and Freedom Mobilization (PFM) in January 1970. PSC's primary goal had been to educate its members and the Graceland and surrounding communities about the war in Vietnam. PSC members wanted Graceland students to be involved in what Walden later termed "the other side of the cornfield" and to resist further American involvement in Vietnam. PFM members, who envisioned their activism continuing beyond U.S. involvement in Vietnam, extended their activities beyond war protest to include war tax resistance, "the environmental crisis," students' rights, antiracism, and anti-poverty campaigns. PFM obtained office space in the Administration Building, situated in the center of the campus. From their basement office, PFM published and distributed its own newsletter. Members maintained antiwar resource material on closed reserve in the college library and showed antiwar films in the Memorial Student Center (MSC). In addition, they used the MSC's skate booth to distribute antiwar literature and as a headquarters for antidraft counseling. ${ }^{47}$

Not content to address only the campus community, PFM took its activism out into the larger community. On Thursday, March 19, 1970, PFM members drove 15 miles northeast of Lamoni to Leon, Iowa, home of the Decatur County draft board. Greg Walden reported that the group "attempted to nonviolently shut down the local draft board, by engaging the clerk in a serious dialogue about her job and the draft in general." After meeting inside with the unresponsive clerk, the students moved

46. Graceland Tower, 12 and 20 November and 11 December 1969.

47. Greg Walden to Howard Booth, [n.d.], Booth Papers; Graybill and Graybill, "History," 29; Stephen A. Byrn, interview by author, Lamoni, 27 October 1988; Peace and Freedom Mobilization Bulletin, passim. 
outside. As they sang songs on the lawn in front of the draft board office, a local draft board member and World War II veteran who was angered by the group's presence approached them. Walden offered him some PFM literature. Without bothering to look at it, the gentleman threw it on the ground and stepped on it, remarking that the students were "yellow from the toes up." Sheriff Deral Houck watched the confrontation. Crossing the street, Houck made the Graceland students gather their belongings and follow him. "It was really scary," recalls Greg Sutherland. "We all thought we were going to jail." After explaining their purpose, the students were released on conditional terms. Sheriff Houck allowed them to demonstrate outside but prohibited them from lobbying the clerk inside the draft board's office. The activities in Leon fell far short of stopping or even disrupting draft practices in Decatur County. The local newspaper did not even recognize their actions. ${ }^{48}$

Undaunted, PFM continued its efforts to educate its members and the surrounding community on the war and other issues. PFM organized road trips to hear speakers such as Dr. Benjamin Spock, famed pediatrician and peace worker, at Drake University in Des Moines on April 6; William Kuntsler, defense attorney for the Chicago Eight, who addressed an audience at Simpson College on April 14; and Paul Ehrlich, author of The Population Bomb, who spoke at Iowa State University and Grinnell College on April 24. That same month PFM canvassed Lamoni with a war cost leaflet that outlined several ways taxpayers could "avoid paying part or all of the taxes which support militarism." Working with the Student Academic Council, Walden and his group helped sponsor Earth Day at Graceland on April 22. ${ }^{49}$

All of this antiwar activity during the 1969-70 academic year did not go unnoticed by college alumni. Gwen B. Chapman, for instance, complained that outsiders "could very well reach the conclusion that Graceland has turned into a bastion of the extreme left." Mrs. Delbert D. Smith warned that the October

48. Graceland Tower, 17 April 1970; Greg Sutherland, interview by author, Lamoni, 9 March 1989. Walden reported that Sheriff Houck had asked the Leon Journal-Reporter not to print a story concerning the March 19 activities. Graceland Tower, 17 April 1970.

49. Peace and Freedom Mobilization Bulletin, 13 and 28 April 1970, Booth Papers. 
moratorium activities at Graceland were making it difficult for people like her to support the college. ${ }^{50}$

On the other hand, more radical elements remained dissatisfied with the level of antiwar activity on campus. Members of Students for a Democratic Society at Graceland, for example, publicly exhorted others to take an active role in stopping the war. Writing in the campus newspaper, Jan Bergman maintained that Graceland was "a campus of plastic people living in a plastic dream land" and asked how students could be happy when their friends were dying in Vietnam. "I think it's time that we spoke out as we feel," Bergman wrote, "time the real people on this campus rose from the mud and spoke the thoughts that are being hidden inside them. ... Rise up and be counted as a person of conviction. Join the S.D.S."

Near the end of the 1969-70 academic year, the shooting of four Kent State University students by Ohio National Guard forces on May 4 raised the possibility of stirring more radical action. Reactions to the shootings varied across the country. ${ }^{52}$

50. Graceland Tower, 13 November 1969 and 23 January 1970.

51. Graceland Tower, 25 September 1969; see also ibid., 9 October 1969. Much has been written about the SDS. See, for example, Kirkpatrick Sale, SDS: Ten Years Toward a Revolution (New York, 1973); G. Louis Heath, ed., Vandals in the Bomb Factory: The History and Literature of the Students for a Democratic Society (Metuchen, NJ, 1976); and Alan Adelson, SDS: A Profile (New York, 1972). For insiders' accounts, see James Miller, Democracy Is in the Streets: From Port Huron to the Siege of Chicago (New York, 1987); Todd Gitlin, The Sixties: Years of Hope, Days of Rage (New York, 1987); Tom Hayden, Reunion: A Memoir (New York, 1988); Eleanor Langer, "Notes for the Next Time: A Memoir of the 1960s," Working Papers for a New Society 1 (Fall 1973), 48-83; and Judith E. Smith, "When the Personal Became Political: Re-viewing Harvard SDS," Radical America 22 (1988), 30-35.

52. There is voluminous literature on the Kent State killings. See the annotated bibliography in Scott Bills, ed., Kent State/May 4: Echoes Through a Decade, 2d ed. (Kent, OH, 1988), 251-314. For an excellent survey of events in Kent between April 30 and May 4, 1970, see Lesley Wischmann, "Four Dead in Ohio," American History Illustrated 25 (1990), 24-33, 70-73. For the aftermath of the Kent State killings at other state universities, see Mitchell K. Hall, "'A Crack in Time': The Response of Students at the University of Kentucky to the Tragedy at Kent State, May 1970," Register of the Kentucky Historical Society 83 (1985), 3663; Kenneth Heineman, "A Time of War and a Time of Peace: The Anti-Vietnam War Movement at Michigan State University, 1965-1970," Peace \& Change 14 (1989), 285-323; Joan N. Kaderavek, "Pragmatic Leadership During the Kent State Crisis: William T. Jerome III and Bowling Green State University," Northwest Ohio Quarterly 65 (1993), 30-43; and Stephen White, "UNL Student 
College and university communities erupted in protest. Activists organized student strikes at 30 percent of the nation's 2,500 campuses. "All in all, it was by far the largest number of students ever to demonstrate in a single spasm," writes Todd Gitlin. "Aftershocks went on rumbling. At least seventy-five campuses stayed closed for the rest of the school year." ${ }^{\prime 53}$

At Graceland College there was no student strike as there was, for example, at the University of Iowa and at Grinnell College, where striking activists outside the ROTC building generated enough support to shut down the college before the spring semester ended. Candy Morgan reported in the Graceland Tower that she had not talked "to more than two students who have mentioned the Kent State incident and five who happened to be in a room when the Cambodian invasion was discussed. ${ }^{\prime 54} \mathrm{PFM}$ bulletins in May stressed antidraft, environmental, and antipoverty concerns, and on May 11 the group sponsored balloting in support of the Gates Commission's recommendation that an all-volunteer army replace the draft after June 30, $1971 .^{55}$

If reaction to the Kent State shootings was muted at Graceland, there was total silence in response to equally serious incidents in other communities. Often silences are illuminating. At Graceland they suggest the limits of reform activism. Early in February 1968, heavily armed police officers shot 27 students and killed Samuel Hammond, Delano Middleton, and Henry Smith at South Carolina State College, a predominantly AfricanAmerican school in Orangeburg. Ten days after the shootings at Kent State University on May 4, 1970, law enforcement officials fired on and killed two African-American students and wounded twelve others in a women's dormitory at Jackson State College in Mississippi. On August 29, 1970, in East Los Angeles, Chicana and Chicano activists staged the largest antiwar demonstration ever organized by Mexican Americans in the United States.

Reaction to the Cambodian Incursion and the Kent State Shootings, May 1970," Nebraska History 75 (1994), 261-71. For Iowa campuses, see Matthew Boyle, "Serving the Cause of Peace: The Iowa Campuses' Vietnam Protest," Palimpsest 63 (1982), 142-46.

53. Gitlin, The Sixties, 410 .

54. Graceland Tower, 11 May 1970.

55. Peace and Freedom Mobilization Bulletin, 8 and 11 May 1970, Booth Papers. 
Hundreds of helmeted police attacked the peaceful demonstrators, injuring 61 people and killing three others, including Ruben Salazar, a respected columnist for the Los Angeles Times and news director for a Spanish-language television station. There is no evidence of any public reaction at Graceland to any of these events. ${ }^{56} \mathrm{~A}$ group of seniors with more immediate and local needs circulated a petition protesting the cost of graduation robes; another group lobbied the dean of students after the senior banquet had been canceled; and a group of unidentified students trapped a cow in the lounge of a women's dormitory. ${ }^{57}$

In response to events following the Kent State killings, however, a group of Graceland students did travel to Washington, D.C., where Greg Walden testified on May 22 along with 62 other witnesses before a House subcommittee convened to hold hearings on student views toward U.S. policy in Southeast Asia. In his statement, Walden asserted that all of his attempts to bring the outrage and tragedy to rural Iowa were "met with indifference or token involvement." He called on Congress to provide the moral leadership needed "to make Government responsive to the human needs" he believed went unattended by the Nixon administration. ${ }^{58}$

Walden believed that he and others had been duped by RLDS leaders, elected officials, and the popular media into supporting U.S. involvement in the war in Vietnam and deceived by these same people into enabling capitalist exploitation of labor and the environment. "For the sake of my own conscience, this Nation, and humanity at large," Walden told a sympathetic audience in the main committee room of the Foreign Affairs Committee in 1970, "I simply cannot play out my life in the privileged, uninvolved role which my parents, schooling, and

56. See Jack Nelson and Jack Bass, The Orangeburg Massacre (1970; reprint, Macon, GA, 1984); Tim Spofford, Lynch Street: The May 1970 Slayings at Jackson State College (Kent, $\mathrm{OH}, 1988$ ); and Mario T. García's introduction to Ruben Salazar, Border Correspondent: Selected Writings, 1955-1970, ed. Mario T. García (Berkeley, CA, 1995), 1-38, especially 1-4. See also Martínez, "Histories of 'the Sixties': A Certain Absence of Color."

57. Graceland Tower, 11 May 1970.

58. Greg Walden, in U.S. Congress, House, Ad Hoc Committee on Student Views Toward United States Policy in Southeast Asia, Hearings, 91st Cong., 2d sess. (Washington, DC, 1970), 238. 
society have laid out before me." Instead, he insisted, he had to become relevant to the country's culture and society."

Following the 1969-70 academic year, Walden, one of Graceland's leading advocates of antidraft and antiwar projects, as well as a leading proponent of meaningful student participation in college government and defender of civil rights enterprises, transferred from Graceland to Michigan State University. There he hoped to find more people committed to ending the war and expected to participate in efforts to advance broader political reforms. Although PFM had a mailing list of more than 100 people, sources for operating funds and local targets for protest always had been difficult to identify. Walden himself admitted privately to a friend during the summer of 1970 that, except for their antidraft actions in Leon, "very few people put themselves out." From his perspective, he had continually met apathy and often felt that participation was insufficient. ${ }^{60}$

Walden was not the only Graceland student to hope others would "become involved in and concerned with the problems of the world" and then to become disillusioned when that seemed not to happen. After only a few short months of activity, PFM members felt that they had only minimal accomplishments to show for their efforts. Despite a statement defining PFM in the 1970-71 student handbook, sustained opposition to the war in Vietnam at Graceland effectively ground to a halt in May $1970 .{ }^{61}$

The collapse of PFM marked the end of sustained organized antiwar activity on the Graceland campus. Yet symbolic statements and ad hoc actions continued well into the 1972-73 school year. In 1971 five Graceland students, including Bob Tilden, who was also a reporter for the Lamoni Chronicle, participated in May Day activities in Washington, D.C., the last major antiwar demonstration and one of the largest experiments in civil disobedience in U.S. history. "My most memorable experience," Tilden told Tower journalist Larry Moffett, "was getting gassed, maced, and clubbed-all in five minutes. ... But the most scary

59. Ibid., 239.

60. Ibid., 239; Greg Walden to Greg Sutherland, 25 September 1970, Private Papers of Greg Sutherland, Graceland College, Lamoni.

61. Ibid. 
thing I think was the right-wingers who took the law into their own hands-western style-you know, businessmen with pipes in their hands who were going to take on the protestors by themselves when their [cars were] blocked or stopped. ${ }^{\prime 62}$

After 1970, and especially after the U.S. military began bombing Cambodia, Laos, and North Vietnam, criticism of the Nixon administration's Vietnam policy became more commonplace even as it became less organized. Greg Dawson, in his last assignment for a speech class in 1972, tried to convince students in the Commons during the lunch rush that American foreign policy was unhealthy. He argued that Nixon continued to escalate the war in Vietnam and asked Graceland students to get involved in ending the war. On January 20, 1973, a Saturday, Graceland students joined a national protest by wearing black armbands during Nixon's inauguration. The school paper claimed that wearing the armbands was both a "protest" and a "chance to voice feelings on the war." Dayle Bethel defined the protest as "a re-emphasis of the plea that has been made so many times to end the war in Southeast Asia, to halt the mass killing of other human beings, to admit the absurdity and error of our role in the destruction of the tiny nation of Vietnam and to end that role." ${ }^{163}$

AS SUPPORT for antiwar activism lost ground, local reform activism found another outlet: the movement to end institutional practices that treated women and men differently. As early as February 1968, seven months before a hundred feminists gathered in Atlantic City to protest the Miss America Pageant, reform-minded students at Graceland challenged "late hours," rules governing dormitory life at Graceland. In September 1969

62. Graceland Tower, 17 May 1971. On the May Day activities and their impact, see George W. Hopkins, "'May Day' 1971: Civil Disobedience and the Vietnam Antiwar Movement," in Give Peace a Chance, ed. Small and Hoover, 71-88.

63. Graceland Tower, 5 May 1972 and 19 January 1973. Black armbands as symbols of antiwar debate in Iowa dated back to December 1965, when a group of Des Moines high school students used them to protest U.S. military action in Vietnam. See John W. Johnson, The Struggle for Student Rights: Tinker v. Des Moines and the 1960s (Lawrence, KS, 1997); and William Eckhardt, "The Black Armband Story," Journal of Human Relations 17 (1969), 495-515. 
a group of women asked for "a review of late hours," and in September 1970 Greg Walden privately suggested in a letter from Michigan that Greg Sutherland stage a "sit-in for some worthy purpose like girls' hours. ${ }^{\prime \prime 4}$

Graceland's campus environment generally and student housing specifically served as crucial "social spaces" through which women developed a heightened consciousness as a group discriminated against and deserving certain rights and prerogatives. Although they did not follow most early women's liberation groups in attributing women's oppression to capitalism, Graceland women did cast Graceland men in political terms, publicly asserted their independence, and forthrightly displayed their talents in the wider campus community. Graceland women were not people numbed by restrictive social practices looking for husbands (as too many assumed), but women with varied dreams, goals, tenacity, and intellect. Demanding fair treatment and removing gendered practices from the housing code represented an opportunity to demonstrate their shrewdness and dedication to a common cause. ${ }^{65}$ Their actions also suggest that

64. Graceland Tower, 16 February 1968; Newell R. Yates to Eldon Anderson, 23 September 1969, AGC; Walden to Sutherland, 25 September 1970. "Girls' hours" were the times by which women were required to be signed into their residence halls. A "late minute" was given for forgetting to sign in. Women returning late were required to record the number of minutes they were late. Each woman was allowed 19 late minutes per semester. Upon receiving her twentieth, an offender was penalized with a "campus," which meant that an offender would be confined to her room by 7:00 p.m., after which time she could not shower or receive local phone calls or visitors. Key cards were available for upperclassmen or any woman over 21, yet rules and regulations for their use were ambiguous and cumbersome at best. Rules and regulations for women's hours are outlined in Graybill and Graybill, eds., "History," 4, 12-15.

65. Sara Evans has defined social space as an area "within which members of an oppressed group can develop an independent sense of worth in contrast to their received definitions of second-class or inferior citizens." See Evans, Personal Politics, 219; and Harry Chatten Boyt and Sara M. Evans, Free Spaces: The Sources of Democratic Change in America (Chicago, 1992). See also Gillian Rose, Feminism and Geography: The Limits of Geographical Knowledge (Minneapolis, 1993). Evans suggests that the civil rights movement and SDS were important training grounds for women in the liberation movement. At Graceland, it appears, the important social spaces within women's dormitories and the male-dominated spaces of the Cooperative Government Association and antiwar protest of PFM, but not civil rights, "were sources for the intellectual foundation and cultural orientation for the women's liberation movement." See also Alice Echols, "Nothing Distant About It: Women's Liberation and Sixties Radical- 
reform activism not only contributed to institutional renewal; it also was absorbed by the institutions it sought to reform.

Like other areas of reform activism, this challenge to policies affecting women students met resistance from those who defended existing practices. Some of them maintained that women benefited from late hours because women needed ample study and sleep time. Others argued that requiring women to be in by ten provided assurance to parents who might need to locate their daughters in the event of a family emergency. In addition, the policy allowed administrators to claim that female students were safely housed within the dormitory halls after dark; late hours provided an illusion that Graceland protected its "girls." Another line of argument was represented by Les Kaler, a selfidentified older, non-traditional student, who reminded protestors that Graceland was a private institution. "If you have your choice and you know what Graceland stands for and it does not suit your needs," he said, "Why come?" In other words, people knew the rules before coming to Graceland; therefore, disgruntled students had no right to complain or even try to change rules after they made the choice to be there. ${ }^{66}$

Reform activists, women and men, increasingly objected to justifications like Kaler's and questioned women's unequal place in campus life. "It does not logically follow that only women need sleep at night," wrote one female student in 1970. "If she isn't mature enough to take care of herself," another student told a Graceland Tower interviewer in February 1970, "she isn't mature enough to be at college." Candy Morgan, editor of the Graceland Tower in 1969-70, maintained that support for women's hours was based on "a fear that no one is talking about but quite a few people are thinking: pregnancy. In thinking through the fears for why anyone could have devised women's hours in the first place (and it almost had to be a man)," she added, "I

ism," in The Sixties: From Memory to History, ed. David Farber, 149-74 (Chapel Hill, NC, 1994); Jennifer Ann Frost, "Participatory Politics: Community Organizing, Gender, and the New Left in the 1960s" (Ph.D. diss., University of Wisconsin-Madison, 1996); and Annie Popkin, in From Camelot to Kent State: The Sixties Experience in the Words of Those Who Lived It, ed. Joan Morrison and Robert K. Morrison (New York, 1987), 181-85.

66. Graceland Tower, 6 February 1970. 
can find few other fears or reasons for locking girls up at night." A number of women and men supported an end to women's hours by 1970 . Dennis McAlister argued that late hours should be abolished because "there is no chance for growth and maturity to develop with hours restricted." Similarly, Chris Piatt thought that late hours "subjected [women] to authoritarian control" and an "obvious double standard." Many students believed that the rules were absurd because late hours required women to be in the dorms before the college library closed its doors and because Graceland men were not held to the same standards. Housing codes required only that men file an Emergency Notification Card with their house president the night before they were planning to leave the campus - a requirement that was largely ignored and often not enforced. ${ }^{67}$

In February 1971, Graceland women in Ananta House of Tess Morgan Hall (one of the women's dormitories) refused to comply with sign-in procedures they thought represented "the injustice of the double standard," then worked through the Cooperative Government Association to abolish late hours. Their refusal to sign in, according to house member and student senator Kay Axtell, was "an expression of ... personal objection to the present hours system." The action, according to Axtell, "was meant neither as a threat nor a demand" but, almost apologetically (using stereotypes of "proper" female behavior to her advantage), as an "avenue of expression" aimed at bringing the issue before the administration. ${ }^{68}$

In talking with a number of male students, head residents, and house presidents, Axtell "found a considerable degree of apathy throughout the male populace." This lack of concern encouraged Axtell and Judy Stearman to make a motion in the student senate to extend the signing-in requirement "to the entire student population, not just half." Their motive, according to Axtell, was "to jolt the state of indifference many students can be found degenerating into simply because the outcome of the struggle may not directly affect them." Axtell argued that late

67. Graceland Tower, 6 February 1970; Marian Killpack, student and women's head resident, interview by author, Lamoni, 8 June 1989; Jim Johnson, interview by author, Lamoni, 7 March 1989; Sutherland interview; Byrn interview.

68. Graceland Tower, 12 March 1971. 
hours did not provide the information needed to locate a student, did not apply to daylight hours, and did not permit women students the opportunity to make personal judgments of their own. ${ }^{69}$

The strategy of working through the CGA required the cooperation of both sympathetic men and student government officers who were not necessarily sympathetic but who nonetheless met their obligations as elected representatives. ${ }^{70}$ Neither came easily. Writing in response to the Ananta House action, Graceland Tower reporter Larry Moffett regretted "the theatrics women senators used to introduce the proposal to the senate. The move was cute," he wrote, "but we think it ended up a cheap trick, alienating support that could have been theirs had they the courage to tackle the problem head on. ${ }^{\prime \prime 1}$ Nonetheless, the strategy worked. On March 10 the student senate recommended that the college "shift the responsibility for being able to locate a student to the student." In correspondence with the Executive Cabinet the following August, President Higdon unofficially vetoed Axtell's measure. "After some discussion of the action to abolish sign-in by women," Higdon wrote, "I have come to feel that the matter turns on the obligations students and parents feel the college has with up-to-date knowledge of student whereabouts." ${ }^{172}$ Higdon's veto of the proposal left fe-

69. Minutes, Cooperative Government Association, Senate, 10 March 1971, AGC. 70. Constitution, Cooperative Government Association of Graceland College, AGC; see esp. art. 3, sec. A, and art. 4, sec. C. For a brief review of the authority and areas of responsibility of the CGA and its officers, see Graybill and Graybill, eds., "History," 17, 48. According to the CGA constitution, the CGA's legislative authority was vested in the senate. Yet only the CGA president was "empowered to make representation on behalf of the Executive Cabinet to the President of the College." No other CGA officer shared this responsibility. Therefore, if a motion passed by the senate was not placed on the agenda of the Executive Cabinet, that issue could not be officially discussed and could be -as it was in the case of "girls' hours"-used by opponents of reform as a roadblock to change. David Clinefelter, speaker of the senate and member of the Executive Cabinet, promised "immediate cabinet action," but the senate motion was not recorded anywhere in the 1970-71 official minutes and Clinefelter was not present at two of the last five meetings of the 1970-71 Executive Cabinet. Apparently the issue was discussed privately, however. See Minutes, Cooperative Government Association, Executive Cabinet, 1970-71, passim, AGC.

71. Graceland Tower, 5 March 1971.

72. Graceland Tower, 23 April 1971. 
male protestors wondering why the administration ignored or at least failed to consider that only women were required to sign in. Cami Kirk, for example, suggested that late hours were "especially unfair" because they required "twenty-one year old women ... be in or otherwise accounted for by specified hours every night when there was no such restriction placed on nineteen year old men." ${ }^{\prime 73}$

The movement to abolish women's hours surfaced again in the newly functioning Graceland Student Government a year later in 1972. Near the end of April 1972, Janet Yarlot introduced a resolution similar to Axtell's 1971 bill. During floor discussion she moved to eliminate the signing-in procedure and the late minutes penalty. Both motions carried unanimously with an additional appeal that dorm regulations be "consistent concerning both guys and gals." The following day, Dave Clinefelter introduced the measure in an Executive Cabinet meeting, which recommended action. But the senate and Executive Cabinet resolutions were not forwarded to President Higdon during the hectic days preceding final examinations and commencement. The student government did not examine the issue again until September 13. Then in October it forwarded a legislative proposal to President Higdon. This time he agreed to the changes. "Any stranger witnessing the frenzied excitement around the reception desk of Tess Morgan at 9:40 Wednesday night," Cami Kirk wrote in the Graceland Tower, "might have thought that he had entered Graceland's psychiatric ward. Girls were screaming, embracing, and jumping with joy as they signed in for what would be the last time." 74

IN ITS PRESCRIPTIVE LITERATURE-that institutional material distributed through college staff to potential students and possible funding sources-Graceland College emerged for readers as a community of learning that based its corporate life

73. Graceland Tower, 20 October 1972.

74. Minutes, Cooperative Government Association, Senate, 26 April 1972, AGC; Minutes, Cooperative Government Association, Executive Cabinet, 27 April 1972, AGC; Minutes, Graceland Student Government, Senate, 13 September 1972, AGC; Minutes, Graceland Student Government, Executive Cabinet, 22 September 1972, AGC; Graceland Tower, 20 October 1972. 
on abstract ideals such as fellowship, mutual concern, love, respect for individual dignity, and concern for larger world communities. ${ }^{75}$ But those abstract ideals communicated through prescriptive literature and institutional practices were not always fully realized in social and political relations. Between 1965 and 1973, oppositional discourses emerged at Graceland College within what might be thought of as a primarily white Christian fraternity. During those years Graceland emerged as a racialized and gendered social space from which Gracelanders, employing a strategy of political personalism, pointed out tensions and hypocrisy in personal behavior and in structures-such as in the dean of students' "dual role" and in the housing code-then worked to eliminate them. Generally, the wider campus community eventually, though often not easily, responded favorably to the personalized politics of reform activists. For many in rural Lamoni, the personal did become political and the political did become personal as a critical mass of mostly white students, college staff, and professors combined forces to remake Graceland over into the image idealized in prescriptive materials and problematized by white reform activism.

Yet organized antiwar efforts between October 1969 and May 1970 also signified the limits of political personalism at Graceland. Antiwar activism found its greatest success when it concentrated on local concerns. After 1965, the war was always a possible symbol activists could use to generate support for perceived local problems such as a voiceless student government and in loco parentis administrative policies. Greater and increasingly more independent student involvement in college governance and movement toward ending campus practices that treated women and men differently suggest that student and faculty activists set in motion conversations about local concerns that regenerated a sense of community among a sometimes divided population and that rejuvenated members of an administration and a faculty who contributed to what was arguably the institutionalization of new left and feminist criticism. In short, reforming campus governance was easier than ending war.

75. See, for example, Graceland College Official Catalog, 1965-66, 9-10; and Graceland College Bulletin, 1968-69, 8. 
Copyright of Annals of Iowa is the property of State of Iowa, by \& through the State Historical Society of Iowa and its content may not be copied or emailed to multiple sites or posted to a listserv without the copyright holder's express written permission. However, users may print, download, or email articles for individual use. 